by Hisashi Nirei ${ }^{1}$, Adriana Mezzano ${ }^{2}$,Jonas Satkunas ${ }^{3}$, Kunio Furuno $^{4}$, Brian Marker $^{5}$ and Muneki Mitamura ${ }^{6}$

\title{
Environmental problems associated with man- made strata and their potential management
}

\author{
${ }^{1}$ Japan Branch of IUGS-GEM, Geo-pollution Control Agency, Japan. (NPO), Japan. E-mail: nireihisashi@msn.com \\ ${ }^{2}$ Engineering Faculty, Universidad de la República, Montevideo, Uruguay. Julio H y Reissig 565, CP 11200.E-mail: amezz@fing.edu.uy; \\ ${ }^{3}$ Geological Survey of Lithuania, Vilnius, Lithuania. E-mail: jonas.satkunas@lgt.lt \\ ${ }^{4}$ Japan Branch of IUGS-GEM, Katori, Chiba, Japan. E-mail: kuniofurunojp@ gmail.com \\ ${ }^{5}$ Secretary General of IUGS-GEM, 40 Kingsdown Avenue, London W13 9PT, United Kingdom. E-mail: brian@amarker.freeserve.co.uk \\ ${ }^{6}$ Osaka City University, Osaka City, Japan. E-mail: mitamrm@sci.osaka-cu.ac.jp
}

Man-made strata occur throughout the world. Also locally called "fill" or "reclaimed land," most man-made strata were formed by industrial activity. Some strata are inert, well consolidated and properly "engineered" for their intended future use. Many other, however, are polluted, contaminated and potentially unstable owing to poor environmental management and monitoring. Such deposits are often stratigraphically complex and thus require site-specific geologic and geotechnical investigation to ensure ground stability and to avoid release of surface, subsurface and airborne pollutants. We have compared various investigative approaches from Uruguay, Lithuania, Japan and England; and therefore now strongly recommend that national, regional and local governments actively identify the magnitude of problems associated with man-made strata within their various jurisdictions. Based on varying terminology, concepts and political, administrative, legal, historical and geological contexts, we find it desirable to use fewer, but more rigorously defined and internationally agreed terms. Environmental assessments of man-made strata should be expanded throughout the world. It is, however, the more developed nations that currently have the greatest problems and costs associated with redevelopment of man-made strata. But such problems can be avoided in industrializing countries if they adopt best management practices, policies and priorities that strategically implement and enforce sound planning and environmental permitting. These procedures can ensure that man-made strata are suitable for their intended use by developing appropriate site investigation, modeling and remediation design, and by implementing appropriate monitoring and recording processes.

\section{Introduction}

Man-made strata, consisting of materials from industrial, construction and other activities, are widespread in many urban and suburban areas but also occur in the open countryside where these often result from mining, quarrying and waste management. Many deposits are relatively recent; however, others are ancient and archaeologically important. In parts of the Middle East such strata date from Neolithic times (Gates 2003). But in developed, and some developing, countries most date from industrialisation between the $17^{\text {th }}$ and $20^{\text {th }}$ centuries (e.g. Teich and Porter 1996; Sugihara Kaoru 1990) and are still accumulating. Many towns and cities expand as time passes resulting in development above earlier man-made deposits. Some deposits are inert and well consolidated (engineered fill); others, however, are polluted, contaminated and potentially unstable. Conversely, de-industrialisation leaves land damaged or derelict (Genske et al 2010).

The IUGS Commission for Geoscience for Environmental Management established a Working group on "Man-Made Strata and Geopollution" in 2009 (www.iugs-gem.org). A major objective of this Group is to produce geoscience information for sustainable use of urbanized land and man-made strata. This paper summarizes some environmental management issues based on experience in Japan, Uruguay, Lithuania and England.

\section{Terminology}

Many terms have been applied to man-made strata and their settings:

- Anthropogenic deposits, man-made strata, made ground, reclaimed land; fill deposits, technosols and artificial soils any significant deposits created by people wherever these are located; and

- urban soils - natural and anthropogenic soils in urban areas.

Other relevant terms are:

- contaminated land - deposits, natural or man-made, affected by past or recent pollution;

- brownfield sites - previously developed land mainly located in urban areas but also occurring in the countryside; and 
- geopollution - processes and products of pollution of both natural and man made strata.

(see, for instance, Alker et al 2000; Lehmann and Stahr 2007; Rossiter, 2007, 2009; Nirie et al., 2010).

\section{The nature of man-made strata}

Many deposits accumulated without any environmental management, including recording of composition, remedial action or adequate monitoring arrangements. Such strata are variable in lithology, grain size, sorting and many other physical and chemical properties (Mather et al., 1996) and many include:

- geological materials excavated either locally or at distance, spread to level sites by filling topographical depressions such as valleys, ponds and old quarries or to make mounds;

- embankments constructed for roads, railways, canals or flood protection from either geological materials and/or industrial deposits such as slag;

- mounds produced for defensive works;

- industrial and agricultural wastes and residues;

- waste management facilities such as landfills, mine tailings ponds and tips;

- construction wastes;

- debris from civil demolition or military damage; and

- material of terrestrial or sub-aqueous origin used to reclaim land from lakes or the sea for development.

Grain sizes of materials range from clay, through sand, silt and gravel, to large slabs of concrete or metal. Some deposits are homogenous but many are mixed, containing organic components such as wood and other wastes, as well as inorganic materials, including concrete, metals, ash, slag and pipes, tiles and other ceramics. The composition reflects the origins of the materials. Deposits may be inert or contaminated with potentially hazardous elements and compounds or organic chemicals from past or contemporary activities; and therefore include biodegradable materials (ICRCL, 1987).

Deposited materials may contain:

- organic or inorganic solid pollutants;

- organic or inorganic liquid pollutants including some that are volatile; and

- gases.

Solid pollutants usually enter man-made strata when industrial wastes are deposited but sometimes originate from re-deposited geological materials. Liquids come from untreated effluents, leakages and accidental spillages but pollutants may also be leached from deposited solids. Gases arise particularly from putrescible materials, especially in landfills, and from chemical reactions within deposits (Nathanail and Bardos, 2004).

The distribution of man-made strata depends on how they were deposited, ranging from rapidly, slowly. sporadically, randomly or systematically (Nirei et al., 2012). This influences contaminant compaction, water content and occurrence of voids. Following deposition, and depending on porosity, man-made deposits may constitute aquifers or aquicludes. Deposition on permeable or impermeable strata influences the degree of hydrogeological continuity between the man-made strata and natural aquifers. Some deposits may rest on geologically weak ground while others conceal preexisting voids such as old wells, mine shafts, storage tanks and cellars. Strata may be disturbed and added to since earlier deposition for instance during drilling, piling and excavation. (Wimpey Environmental Limited and National House Building Council, 1995).

\section{Problems associated with man made strata}

Man-made strata are not always problematic. Some are inert, well compacted and stable (engineered fill), but many are polluted, contaminated and unstable. Solid pollutants include potentially harmful elements and compounds which may be acutely or chronically toxic or carcinogenic to people, livestock, and wildlife or damaging to vegetation. Liquids may also be toxic or carcinogenic. Gases and volatile liquids can be toxic, asphyxiating or explosive. These may remain in place or may migrate through pores, fissures and voids, and along boundaries between depositional layers to cause problems well away from the site, including reduction of surface water quality (Kelly and Lunn, 1999). Volatile liquids and gases may be released into the air causing danger if these accumulate in confined spaces that are entered by people or where sparks or flames might cause fires or explosions.

Groundwater levels within man-made strata may mobilize hazardous substances. If there is no impervious layer beneath, pollutants can be carried down to lower levels affecting groundwater quality.Groundwater levels fluctuate seasonally and annually thus locally enhancing contaminate diffusion (Lerner and Harris, 2009). Particular problems may arise when pumping ceases in areas dewatered for mining or quarrying, with subsequent rising groundwater and resurgence of springs that carry pollutants into the surface drainage (Younger, 2001).

Man-made strata can also be geotechnically weak owing to voids, compressible sediments and waterlogged sands. Accordingly, geotechnical behaviour can be difficult, thus:

- embankments and tips may be steep, or become oversteepened, with erosion leading to slips;

- some ground, particularly saturated silt and fine sand, may liquefy during earthquakes leading to ejection of material at the ground surface, subsidence of structures, release of contaminants and flow into excavations resulting in permanent ground deformation.

- liquefaction can also be caused by vibrations during, for example, pile driving; and

- decomposition of landfill deposits often leads to reduction of volume and ground subsidence in the absence of proper engineering design.

Changes affect hazard and risk at the site. For example, flooding, rising groundwater, site investigation (e.g. sinking boreholes), excavation and piling can cause mobilisation of pollutants into nearby soils and groundwater. Caution is therefore needed when intervening at such sites.

Historical factors also pay a part. Countries such as Japan, the UK and Germany suffered greatly during the second World War, leading to major burial of material stemming from military damage. Such deposits are often poorly recorded and may contain hazardous materials including unexploded ordinance (Greichgauer et al, 2000). Environmental management of man-made strata therefore requires sound understanding of the nature and distribution of contamination, potential instability and associated risks prior to potential development (Barry, 1990). 


\section{Considering the scale of problems at the strategic level}

It is important that man-made strata should be better understood and managed. The only reliable way of assessing potential problems is thorough site investigation. A strategic approach to prioritising remedial and reclamation actions is needed (Griffiths and Smith, 1997). Planners, developers and their consultants need to be aware of potential problems so that these are not overlooked. Also, the development of any national, regional or local strategy for dealing with pollution and contamination requires understanding of the nature and extent of the problem (Office of the Deputy Prime Minister, 2004).

\section{Assessing the area affected}

Various approaches have been taken to assessing the scale of problems depending on historical, geographical and economic factors. An initial survey of the current situation of strategic assessment of problems associated with man-made strata provided representative examples from Uruguay, Lithuania, Japan and England which are presented here.

\section{a) Urbanization and development in Montevideo, Uruguay}

Montevideo, the capital of Uruguay, was founded in December 1726 on the coast of the Rio de la Plata. The metropolitan area now covers almost $526 \mathrm{~km}^{2}$ with a population of 1,338,408 inhabitants. Economic activity was initially dominated by commercial and livestock enterprises. Industrial development commenced in the middle of the $19^{\text {th }}$ century with development of ports, roads and railways. The meat and spinning industries expanded. Mining of construction materials, mainly sand and granitic rocks took place just outside the city limits and, in the early $20^{\text {th }}$ century, limestone was extracted for manufacture of lime and Portland cement (Menzzano et al., 2011). Other areas were used for disposal of domestic, industrial and / or hospital wastes. In the first half of the $20^{\text {th }}$ century, tanneries, textile mills, paint factories, metal industries, oil depots, brick kilns and other industry developed within the suburbs (Fig. 1) close to $19^{\text {th }}$ century mining areas. During the 1960's and 1970's most of these industries closed but contaminated soils in urban and floodplain areas remain. Over the past fifty years, Montevideo grew across and beyond former suburban areas. Two main locations of deposition were: at infilled abandoned quarries; or on flood plains of creeks and streams.

The urban soils of Montevideo, the so-called "technosols," and groundwater pollution are now being studied to characterize profiles, and understand geotechnical behaviour and pollution characteristics. Health problems due to different types of pollution and poor ground conditions have been identified in newly developed areas that contain heavy metals in both soils and groundwater. Data gathered so far are grouped into three categories: old quarry voids; floodplain; and the urban area (Table 1).

The Land Management Plan (Intendencia Municipal de Montevideo, 1999) defines urban, suburban and rural zones that include significant deposits of man-made strata with implications for development. There is a need to further characterize the urban soils and technosols in the City, study their geotechnical behaviour, and develop a consistent definition of urban soils for improved land use planning.
Table 1. Nature of technosols and urban soils in Montevideo, Uruguay

\begin{tabular}{|c|c|c|c|c|}
\hline Type & $\begin{array}{c}\text { Number of } \\
\text { profiles }\end{array}$ & $\begin{array}{c}\text { Nature of } \\
\text { deposit }\end{array}$ & $\begin{array}{l}\text { Thick- } \\
\text { ness }\end{array}$ & Description \\
\hline Technosols & 8 & $\begin{array}{l}\text { Old aban- } \\
\text { doned } \\
\text { quarries }\end{array}$ & $\begin{array}{l}2 \text { to } 5 \mathrm{~m} \\
\text { exceptionally } \\
>10 \mathrm{~m}\end{array}$ & $\begin{array}{l}\text { Masonry and building } \\
\text { debris, scrap metal, house- } \\
\text { hold waste, prunings, etc. }\end{array}$ \\
\hline Technosols & 10 & $\begin{array}{l}\text { Flood- } \\
\text { plain }\end{array}$ & 2 to $3 \mathrm{~m}$ & $\begin{array}{l}\text { Idem and also sediments } \\
\text { removed from elsewhere }\end{array}$ \\
\hline Urban soils & 15 & $\begin{array}{l}\text { Urban } \\
\text { area }\end{array}$ & 2 to $3 \mathrm{~m}$ & $\begin{array}{l}\text { Sediments removed from } \\
\text { elsewhere, industrial waste } \\
\text { (tannery, oils, paints, etc) }\end{array}$ \\
\hline
\end{tabular}

b) Assessment of man-made deposits and contaminated land in Lithuania

Man-made strata are common in urban areas of Lithuania, covering about $3 \%$ of the total area of the country according to the CORINE Land Cover Project data (Vaitkus, 2005). Even outside the urbanized areas man-made strata occur frequently, often associated with geopollution (Kadûnas et al, 1999; Satkûnas et al, 2011).

The principal deposits are associated with:

- urban areas;

- historical fortifications (hill forts, castle mounds etc.);

- landfills and contaminated sites.

Quarry deposits are omitted because these are wholly re-deposited natural sand and gravel.

The thickest urban man-made strata occur in the most populated cities such as Vilnius, Kaunas, Klaipëda, and Šiauliai and often exceed $10 \mathrm{~m}$ in thickness in the older parts of the towns. These consist of mixed natural soils, municipal and construction wastes and top soil. About $26 \mathrm{~km}^{2}$ (more than $16 \%$ of the total area) of the area of Kaunas City, for example, is covered by deposits more than $1 \mathrm{~m}$ thick (Fig. 1).

The extent of man-made strata in Lithuanian urban areas is now assessed by geotechnical investigations and a programme of urban engineering geological mapping. Mapping has been completed at a scale of 1:10 000 in Kaunas, 1:25000 in Klaipëda, 1:50 000 in Điauliai and is in progress at 1:1000 scale for Vilnius. The percentage of cover of man-made strata in urban areas can be estimated from mapping results (Table 2).

\begin{tabular}{lcl}
\multicolumn{3}{l}{ Table 2. Estimates of the extent of man-made strata in urban areas } \\
\hline Type of area & $\mathrm{km}^{2}$ & $\%$ \\
\hline Territory of Lithuania & $65000 \mathrm{~km}^{2}$ & $100 \%$ \\
Urbanized areas & $1950 \mathrm{~km}^{2}$ & $3 \%$ \\
$\begin{array}{l}\text { Estimated area of man made } \\
\text { strata in urban territories }\end{array}$ & $312 \mathrm{~km}^{2}$ & $\begin{array}{l}16 \% \text { (of urban } \\
\text { areas) }\end{array}$ \\
\hline
\end{tabular}

Deposits associated with fortifications, commonly hill forts dating from the $5^{\text {th }}$ and $6^{\text {th }}$ centuries onwards, occur within and outside major cities, located strategically near major roads, larger settlements or natural barriers such as rivers. Natural hills were often reshaped to meet defensive requirements, but sometimes mounds are wholly manmade. Deposits consist of natural soil and construction waste, often with layers of cultural debris, charcoal, artifacts and topsoil (Satkûnas et al, 2008) and are, in places, subject to slope instability (Mikšys et al, 2002).

Municipal landfills include: small deposits near villages, medium sites serving towns; and large sites serving cities. There were about 20-30 landfills of various scale in each municipality before Lithuania joined the European Union. After 2008 most were closed and 10 properly controlled regional landfills were installed. Waste from the 


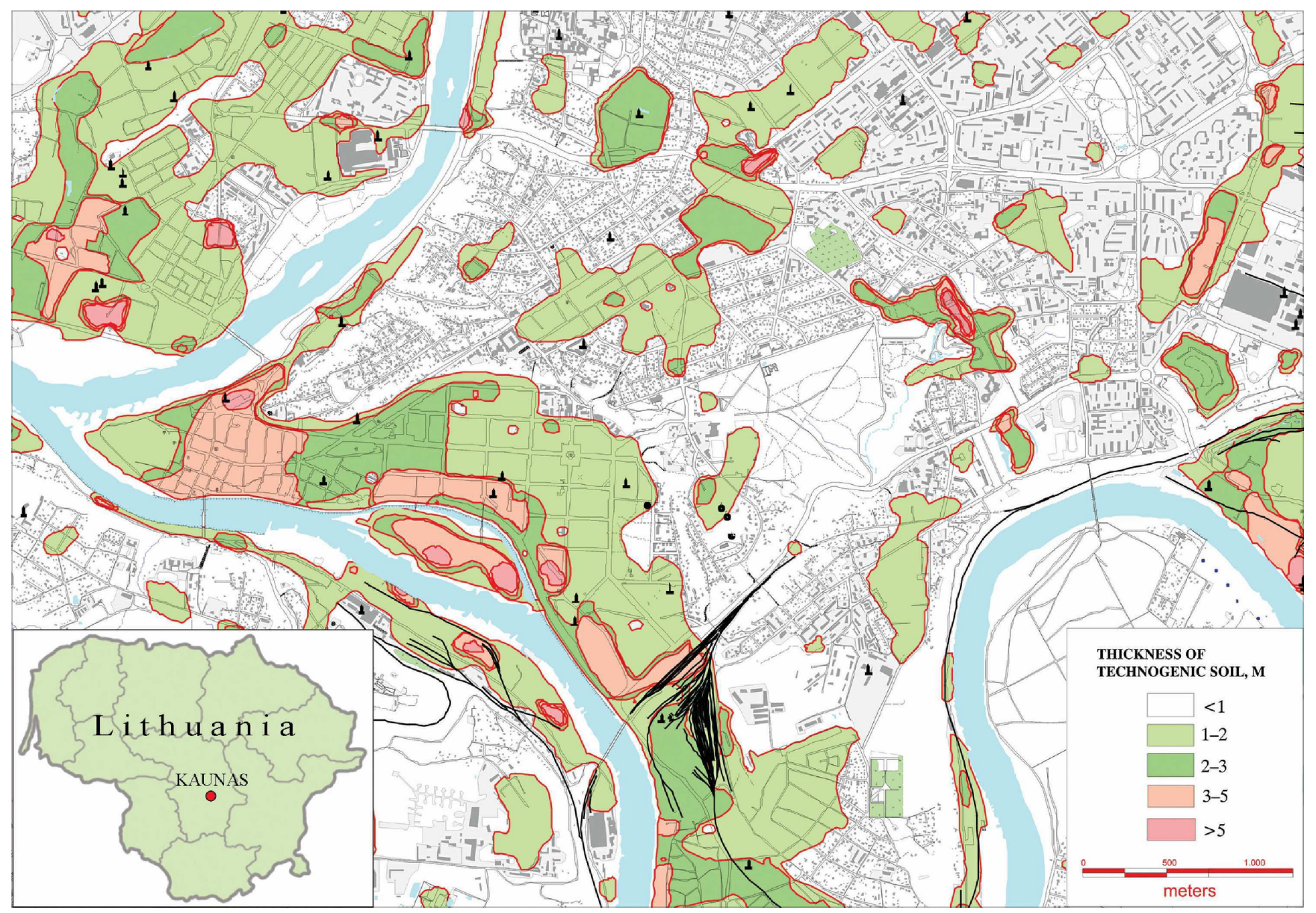

Figure 1. Thickness of man-made strata in Kaunas (Paukðtë and Mikulënas, 2004).

smallest sites was removed to medium-sized facilities and other closed sites were restored. Remaining sites cover some $8.63 \mathrm{~km}^{2}$ with deposits some 10-20 m thick (Vaitkus op.cit.) or, in the large city landfills, $20-40 \mathrm{~m}$.

The total estimated volume of man-made strata in urban areas, landfills and hill forts in Lithuania is about $0.7966 \mathrm{~km}^{3}$, or about $12,256 \mathrm{~m}^{3}$ per $\mathrm{km}^{2}$ of the total territory (Table 3 ).

\begin{tabular}{lcl}
\multicolumn{2}{c}{ Table 3. Estimated volume of man-made strata } \\
\hline $\begin{array}{l}\text { Volume of man-made } \\
\text { strata in: }\end{array}$ & $\mathrm{Km}^{3}$ & $\begin{array}{l}\text { Volume of man made } \\
\text { strata }\left(\mathrm{m}^{3} / 1 \mathrm{~km}^{2} \text { of the }\right. \\
\text { country territory) }\end{array}$ \\
\hline Urban area & 0.6240 & 12256 \\
Landfills (total number 850$)$ & 0.1726 & \\
Hill forts (total number 840) & 0.000029 & \\
Total & 0.7966 & \\
\hline
\end{tabular}

The extent of contaminated land in Lithuania has also been considered. Since 1999, the Lithuanian Geological Survey (LGT) has compiled an inventory of potential contamination sources and manages an Integrated Digital State Information System of Contamination Sites (ISCS). Sites are classified into 4 types and over 40 subtypes including contamination arising from:

- industry, energy, transport and service sectors;

- waste management;

- livestock objects; and

- accidental chemical spills.

but not including military damage. By the end of August 2010 data
Table 4. The nature of potentially contaminated sites in Lithuania

\begin{tabular}{lcccc}
\hline Status & $\begin{array}{c}\text { Industry, energy, } \\
\text { transport and } \\
\text { service sectors }\end{array}$ & $\begin{array}{c}\text { Waste } \\
\text { management }\end{array}$ & Livestock & $\begin{array}{c}\text { Accidental } \\
\text { chemical spills* }\end{array}$ \\
\hline Operational & 2745 & 1953 & 731 & \\
Inoperative & 958 & 784 & 713 & \\
Demolished & 647 & 887 & 1018 & \\
Fire damaged & 2 & 21 & 3 & \\
Reconstructed & 114 & 89 & 31 & \\
Remediated & 33 & 305 & 1 & \\
Total & 4499 & 4039 & 2497 & \\
\hline
\end{tabular}

*limited records due to difficulties of collecting data in the field and reluctance of organizations responsible for spill management.

on 11038 potentially contamination sites were stored in the ISCS (Table 4).

These data can be used for analysis of the spatial distribution of sites and potential soil or groundwater contamination. The total area covered by these sites is about $380 \mathrm{~km}^{2}$. Taking a possible average thickness of man-made strata as $1.2 \mathrm{~m}$ (the average depth of ground freezing, minimal depth for water supply infrastructure, and close to the average depth to groundwater) the total amount of man-made and potentially contaminated soil could be about $0.456 \mathrm{~km}^{3}$ or $7015 \mathrm{~m}^{3}$ per $1 \mathrm{~km}^{2}$ of the area of the country. However, that could be an underestimate.

\section{c) Japan}

Assessment of problems associated with man-made strata in Japan 
is at an early stage. A study carried out in Osaka (Mitamura et al, 2011) is taking place in hilly areas underlain by Plio-Pleistocene sediments consisting of unconsolidated mud, sand and gravel. New areas have been developed since the late 1960's. Hills have been levelled and the spoil used to infill adjacent valleys. Filled areas are normally stable for housing foundations but many failures have occurred due to slope failure and liquefaction during earthquakes (Mitamura, 2003).

Fill sediments are generally sands or clayey. Characteristics are generally assessed by comparison with the nearby undisturbed geology. Work has been undertaken in three parts of Osaka, using GIS to:

- compare old and current topographical maps to estimate the thickness of fill;

- determine locations of filled irrigation ponds which are associated with liquefaction; and

- estimate current slope angles from digital elevation model data.

Earthquake susceptibility is high where slope and high liquefaction potential coincide but is highest in areas of flexure and uplift of nearby Quaternary formations. Some findings of the findings are summarised in Table 5.

Table 5. Factors influencing ground conditions in the three study areas in Osaka

\begin{tabular}{|c|c|c|c|}
\hline Factor & Senri Hills & Senboku Hills & Habikino Hills \\
\hline $\begin{array}{l}\text { Area of valley } \\
\text { fills (hectares) }\end{array}$ & 1236 & 1415 & 1184 \\
\hline $\begin{array}{l}\text { Area already } \\
\text { developed (\%) }\end{array}$ & 47.1 & 46.7 & 58.1 \\
\hline Sandy fill (\%) & 91.4 & 79.7 & 80.0 \\
\hline $\begin{array}{l}\text { Nature of } \\
\text { sediments }\end{array}$ & $\begin{array}{l}91.4 \% \text { but muddy } \\
\text { sediments from } \\
\text { some horizons }\end{array}$ & $\begin{array}{l}\text { Muddy sediments } \\
\text { less than } 50 \% \text { of } \\
\text { deposits }\end{array}$ & $\begin{array}{l}\text { Muddy sediments } \\
\text { less than } 50 \% \text { of } \\
\text { deposits }\end{array}$ \\
\hline $\begin{array}{l}\text { Thickness of } \\
\text { fill }\end{array}$ & $\begin{array}{l}88 \% \text { less than } 10 \mathrm{~m} \text {. } \\
\text { In general the eastern } \\
\text { fills are thicker, with } \\
\text { local occurrences in } \\
\text { excess of } 15 \mathrm{~m}\end{array}$ & $\begin{array}{l}\text { Fills on the bottom } \\
\text { of the main valley } \\
\text { and in the north in } \\
\text { the east exceed } \\
15 \mathrm{~m}\end{array}$ & $\begin{array}{l}\text { Fills less than } 10 \mathrm{~m} \\
\text { widely distributed } \\
\text { but thick fills occur } \\
\text { in the axial region } \\
\text { of the hills }\end{array}$ \\
\hline Slope angle & $\begin{array}{l}90 \% \text { of area has slope } \\
\text { angles of less than } 6^{\circ}\end{array}$ & $\begin{array}{l}90 \% \text { of area has } \\
\text { slope angles less } \\
\text { than } 6^{\circ}\end{array}$ & $\begin{array}{l}90 \% \text { of area has } \\
\text { slope angles less } \\
\text { than } 6^{\circ}\end{array}$ \\
\hline $\begin{array}{l}\text { Former ponds } \\
\text { (numbers) }\end{array}$ & 760 & 390 & 334 \\
\hline
\end{tabular}

Source: Mitamura et al. (2011)

Earthquake susceptibility is influenced by these factors. The researchers attributed scores to the various factors that influence susceptibility (Table 6) and applied these to the study area to provide susceptibility scores (Table 7).

Further work is needed to better evaluate the physical and mechanical properties of the fills. Similar work will be undertaken in other major cities in Japan.

Soil contamination was recognised as long ago as the late $19^{\text {th }}$ century with numerous examples identified subsequently. In 1976 that the Waste Disposal and Public Cleansing Act was amended to cover waste disposal facilities (Tokunaga, 1996). The Environment Agency (later Ministry of the Environment) established: environmental quality standards for soil in 1991 followed by survey and countermeasure guidelines for soil and groundwater contamination in 1999. A Contaminated Soil Countermeasures Law came into force in 2002 (amended in 2005). That law clarified the responsibilities of
Table 6. Scores attributed to each factor contributing to earthquake susceptibility

\begin{tabular}{llcc}
\hline Item & Category & \multicolumn{2}{c}{ Susceptibility score } \\
& & Sandy fill & Muddy fill \\
\hline Thickness of fill & $15 \mathrm{~m}+$ & 0.25 & 1.00 \\
& $10 \mathrm{~m}-15 \mathrm{~m}$ & 0.50 & 0.75 \\
& $5 \mathrm{~m}-10 \mathrm{~m}$ & 0.75 & 0.50 \\
& $5 \mathrm{~m}$ & 1.00 & 0.25 \\
Filled pond & Present & & 0.50 \\
Current slope angle & Absent & & 0.00 \\
& $10^{0}+$ & & 1.00 \\
& $8^{0}-10^{0}$ & & 0.80 \\
& $6^{0}-8^{0}$ & & 0.60 \\
& $4^{0}-6^{0}$ & \multicolumn{2}{c}{0.40} \\
& $2^{0}-4^{0}$ & \multicolumn{2}{c}{0.20} \\
& $2^{0}$ & \multicolumn{2}{c}{0.00}
\end{tabular}

Source: Mitamura et al 2011.

Table 7. Susceptibility scores for the three study areas

\begin{tabular}{cccc}
\hline Susceptibility score & $\begin{array}{c}\text { Senri Hills } \\
(\%)\end{array}$ & $\begin{array}{c}\text { Senboku Hills } \\
(\%)\end{array}$ & $\begin{array}{c}\text { Habikino Hills } \\
(\%)\end{array}$ \\
\hline $1.5-2.0$ & 5.4 & 3.8 & 4.5 \\
$1.0-1.5$ & 37.6 & 30.9 & 35.3 \\
$0.5-1.0$ & 47.0 & 48.3 & 45.1 \\
$0.0-0.5$ & 10.1 & 17.0 & 15.0 \\
\hline
\end{tabular}

the polluter and the land owner (Toshikazau 2003). The text can be found at http://www.env.go.jp/en/laws/water/sccact.pdf(in English).

\section{d) Assessment of brownfield land and registration of contaminated land in England}

England had a relatively early industrial revolution and, therefore, an extensive legacy of, often contaminated, man-made strata in many urban areas. It is impractical to undertake site investigations of this ground. A cost-effective approach was to assume that previously developed land that had become damaged or derelict might be potentially contaminated and/or unstable.

The country has extensive historical records so many of these "brown-field sites". Past activities could be identified from old maps, documents and trade directories. In accordance with Part IIA of the Environmental Protection Act 1990 and the Contaminated Land (England) Regulations 2000 (HM Government 1990, 2000), local authorities were required to maintain a public register of contaminated land. Each register contains: remediation notices, declarations and statements; appeals against notices requiring actions to be taken; designations of special sites; notifications of claimed remediation and convictions for offences. This alerts developers and public to possible problems and guides reclamation strategies. National policies favoured the use of brown-field sites for new development rather than using green field land. Grants towards the costs of remediation of derelict and despoiled land encouraged remediation (Pearce, B.I., 1992). Local authorities were asked to respond to surveys of previously developed land each year from 2002 to 2008 . Table 8 shows results for the first and last of those survey years.

\begin{tabular}{cccccc}
\multicolumn{5}{c}{ Table 8. Results of surveys of previously developed land } \\
\hline Year & Area vacant or derelict & $\begin{array}{c}\text { Area in use but with potential } \\
\text { for redevelopment }\end{array}$ & Total area \\
\hline & hectares & $\%$ & Hectares & $\%$ & Hectares \\
\hline 2002 & 41000 & 60 & 25000 & 40 & 66000 \\
2007 & 33600 & 54 & 28520 & 46 & 62130 \\
\hline
\end{tabular}

Source: Department of Communities and Local Government, 2004, 2009. 
This was a fairly successful strategy with the area vacant or derelict decreasing by about 18\% between 2002 and 2007, but grants have now been terminated due to the economic downturn since 2008 . However, while previous land use is a reasonable guide to possibly contaminated land, records of land uses are incomplete and some land uses have contaminates land outside the source site, so caution is needed.

\section{Mapping}

The extent, thickness and characteristics of man-made strata are often poorly mapped or unknown because past geological surveys have focussed on bedrock and natural superficial deposits. It is important that the nature and thickness of man-made strata should be recorded during geological mapping. Valuable information can also be collated from site investigation reports (see, for example, Steeds et al 2000).

Strategic geochemical surveys are important. Many surveys of potentially harmful elements in urban areas have been undertaken over the past few decades (Johnson et al, 2011) but there have been comparatively few published strategic (as opposed to site based) surveys of organic pollutants (e.g. Jensen et al 2011).

Geophysical mapping can also play an important part. For instance, a trial airborne high-resolution electromagnetic survey was undertaken by the British Geological Survey with the Geological Survey of Finland on a $117 \mathrm{~km}^{2}$ area of the north Nottinghamshire coalfield containing coal spoil tips and landfill sites. This successfully detected known tips, landfills and plumes as well as indicating previously unknown pollution from these sources that was later verified through a drilling programme (Beamish et al 2000).

\section{Site investigation}

Careful site investigation is essential both for safe development and the design of cost-effective, risk based investigation strategies (Petts et al 1997). The normal practice, if contamination is suspected, is to undertake initial screening (Bergius and Õberg 1993) and then to make a series of trial pits, trenches or boreholes to evaluate the nature and hydrogeology of the ground and included contaminants, solid, liquid or gas, taking care not to spread contamination. Drilling is usually undertaken on a standard grid pattern with the interval between investigation points being determined by the presumed level of problems at the site. The spacing is adjusted if necessary. Resistivity and geomagnetic/conductivity surveys are used to interpolate between these (Steeds et al., op cit).

Results are often extrapolated using geostatistical methods (Õberg, 2005). A key question is whether standardised grid patterns of investigation are adequate since the chosen interval between sample points might be too wide to detect localised high concentrations of potentially harmful substances and evaluate whether treatment is needed (e.g. Simms and Beckett, 1987; ICE, 1994).

The man-made deposits are usually treated as distinct entities for initial and following, site-specific systematic investigations. Many deposits were laid down at different times and in variable ways. Nevertheless, it is possible to characterize their internal stratigraphy. This was well demonstrated in an experiment at Rokkoh in Japan in which a former quarry was infilled in stages and the subsequent behaviour of solid and liquid contaminants has been monitored (Nirei et al., 2012). This experiment, if continued, would be particularly valuable to understand how the history of man-made strata deposition can improve site-evaluation design.

\section{Discussion and conclusions}

Man-made deposits occur in most industrial and urban areas, but also in the countryside. Such deposits are often associated with geopollution, land instability or poor foundation conditions. Some sites are hazardous while others are constraints to development. It is important to identify sites, properly evaluate them and undertake appropriate remedial work. Thorough site investigation is essential to ensure that ground is safe and suitable for development but caution is needed to avoid hazards to investigators or releases of pollutants into surface or groundwater. It is also important for administrations to identify the scale of the problems so that policies can be developed and action programmes prioritised.

This paper is based on experience in Uruguay, Lithuania, Japan and England but direct comparisons have proved difficult because of the varying terminology and concepts used in these countries. It is important to carefully define terms used in technical work and also to use easily understood terms when communicating with non-specialists about problems. It would be desirable to use fewer, rigorously defined, and internationally agreed terms.

In Montevideo, relatively recent urban expansion accompanied by concern about actual, perceived and potential public health problems, has led to a focus on identifying suspect sites and their characteristics as the first step towards a strategy for dealing with them.

Lithuania declared independence from the former Soviet Union in 1990 and joined the European Union in 2004. The nation therefore had to adapt quite quickly to different political, management, legal and procedural requirements. The emphasis has been placed on compliance with European Directives that control and minimise landfill and require protection and improvement of the quality of surface and groundwater. Therefore problematic sites have been identified throughout the country and the Lithuanian Geological Survey is undertaking drilling to establish the extent of associated problems.

Uruguay and England are situated on stable continental margins while Lithuania is situated well within the continent of Europe. However, Japan is on a geologically active margin. Consequently, Uruguay and England have low seismic hazards; Lithuania seems to be very low; while Japan is subject to some of the strongest earthquakes in the world (Castaños and Lomnitz 2012; Husebye and Mäntyniemi, 2005; Musson and Winter, 1997; Annaka and Yashiro, 1998). Therefore it is not surprising that the Japanese approach has focussed strongly on determining areas that are subject to liquefaction and other instability during earthquakes. England had an early industrial revolution in the early $18^{\text {th }}$ Century and, therefore very extensive industrial land part of which was contaminated. In the second half of the $20^{\text {th }}$ Century, England saw a major decline in formerly extensive manufacturing industries leaving derelict therefore a national priority was to bring these brownfield sites back into productive uses. The focus was therefore on identifying brownfield land and previous land uses and devising strategies to deal with these while leaving the responsibility for evaluating sites to developers and their consultants. Similarly, Japan industrialised in the late $19^{\text {th }}$ Century and developed very rapidly leading to extensive sites with geopollution problems that now need to be dealt with. 
Both the United Kingdom (of which England is a part) and Lithuania are member states of the European Union engaged in harmonising environmental actions. The European Commission has prepared a draft Directive on Soils with the aim of establishing a framework for the protection of soil and amending an earlier Directive which dealt with inventories of contaminated sites. This proposes that Member States shall:

- identify the sites in their national territory where there is a confirmed presence, caused by man, of dangerous substances of such a level that Member States consider they pose a significant risk to human health or the environment, referred to as "contaminated sites";

- evaluate that risk taking into account current and approved future use of the land;

- establish a national inventory of contaminated that shall be made public and reviewed at least every five years; and

- designate a competent authority to be responsible for the identification of contaminated sites.

(European Commission 2006).

Therefore the political, administrative, legal, historical, and geological circumstances in each Nation have influenced the approaches to considering these issues.

It is beneficial, particularly in developing countries, to better understand environmental problems associated with man-made strata. The Working Group has therefore placed a survey form on its website at www.iugs-gem.org and would welcome more contributions.

Until more geographic information is available, it is clear that post-industrial, post-industrial and developed nations have major problems and costs associated with the re-development of land. These problems can be avoided or minimized in currently developing countries if appropriate regulations are put into place and enforced as soon as practicable. Much depends on the dynamics of city and industrial development because industry, if not properly regulated, can cause future contamination and pollution but, in general and for sites affected in the past, it is sensible to:

- assess the nature and extent of potential problems, at a strategic level, and whether the national economy can deal with these and, if so, over what period as a basis for prioritisation of remediation;

- implement a planning and environmental permitting system, properly enforced, to help ensure that land is treated to a standard suitable for its subsequent use;

- ensure that adequate site investigation, modelling and design of remediation measures are undertaken by developers and/or their consultants; and

- implement adequate monitoring processes to ensure that hazards to workers, the public and development are minimised.

Developing countries have an opportunity of avoiding this trend, and major future costs, if operations are properly regulated now.

\section{Acknowledgements}

Thanks for help given in field work are due to Sebastian Huelmo and Juan Alvez, colleagues of Adriana Mezzano at Engineering Faculty in Montevideo.

\section{References}

Alker, S., Joy, V., Roberts, P. and Smith, N., 2000, The definition of brownfield J1 Environmental Planning Management, v.43(1), pp. 49-69.

Annaka, T. and Yashiro, H., 1998, A seismic source model with temporal dependence of large earthquake occurrence for probabalistic seismic hazard analysis in Japan. In: Proc. International conference on computer simulation in risk analysis and hazard mitigation 1, Valencia, Spain, October 1998, Vol.2, pp.233-242.

Barry, D., 1990, Hazards in land recycling In: Fleming, G. (Ed.), Recycling derelict land, Thomas Telford (London), pp. 28-63.

Bergius, K. and Õberg, T., 1993, Initial screening of contaminated land: a comparison of US and Swedish methods Environmental Management, v. 39(2), pp. 226-234.

Beamish, D., Cuss, R. J. and Peart R. J., 2000, Trial airborne environmental and geological survey: an initial appraisal of relevance to land use, BGS Tech report WK/00/3C BGS (Keyworth), 11 p.

Castaños, H. and Lomnitz, C., 2012, A list of significant earthquakes in South America. In: Earthquake disasters in Latin America. Springer Briefs in Earth Sciences. Springer (Heidelburg), pp. 55-56

Department of Communities and Local Government, 2004, National Land Use Database of previously developed brownfield land, 2002, The Stationery Office (London), 22 p.

Department of Communities and Local Government, 2009, National Land Use Database of previously developed brownfield land, 2007, The Stationery Office (London) $72 \mathrm{p}$.

European Commission, 2006, Proposal for a Directive of the European Parliament and of the Council establishing a framework for the protection of soil and amending Directive 2004/35/EC) (2006/0086 COD), European Commission (Brussels) $30 \mathrm{p}$

Gates, C., 2003, Ancient cities: the archaeology of urban life in the ancient Near East and Egypt, Greece and Rome Routledge (London), xx+444 p.

Genske, D.D., Dongbin Huan and Ruff, A., 2010, An assessment tool for land reuse with artificial intelligence method, Internatinoal Journal of Automation and Computing, v. 7(10), pp. 1-8.

Greichgauer, T; Goedecke, G and Zimmerer, K., 2000, Explosive ordnance and recycling of derelict land - only a problem of communication? In: Contaminated soil, 2000, Proc. International FZK/TNO Conference, September 2000, Leipzig Thomas Telford (London), pp. 882-883

Griffiths, G and Smith, S., 1997, Risk assessment and management strategies In: Hester, R E and Harrison, R.M., (Eds.), Issues in Environmental Science and Technology 7, Royal Society of Chemistry (Cambridge), pp. 103-123.

HM Government, 1990, Environmental Protection Act, Part IIA HMSO (London), pp 122-175.

HM Government, 2000, Environmental Protection (England): the Contaminated Land (England) Regulations 2000. Statutory Instrument 2000, No. 227 The Stationery Office (London) 18 p.

Husebye, E.S. and Mäntyniemi, P., 2005, The Kaliningrad, West Russia earthquakes on the $21^{\text {st }}$ September 2004 - surprise events in a very low seismicity area, Physics Earth and Planetary Interiors, v. 153(4), pp. 227236.

ICE, 1994, Contaminated land: investigation, assessment and remediation, Institution of Civil Engineers (London), 90 p.

ICRCL, 1987, Guidance on the assessment and redevelopment of contaminated land. Inter-Departmental Committee on the Reclamation of Contaminated Land Guidance Note 59/83 2nd edition. DOE (London) $102 \mathrm{p}$.

Intendencia Municipal de Montevideo, 1999, Plan de Ordenamiento Territorial de Montevideo.II.3.2. Zonificación Primaria. In: www.chasque.apc.org/ vecinet/pot09.htm.

Jensen, H.K.B., Eggen, O.A., Frøland, S.L. and Skårn, J.S., 2011, Polycyclic aromatic hydrocarbons in urban surface soil in Oslo, Bergen and Trondheim, Norway: $\mathrm{PAH}_{16}$ levels, compositions and ratios. In: Johnson, C.C. et al. (eds.), Mapping the chemical environment in urban areas, pp. $457-472$ 
Johnson, C.C., Demetriades, A., Locutura, J. and Ottesen, R.T., (Eds), 2011, Mapping the chemical environment in urban areas Wiley-Blackwell (Chichester), xiii+616 p.

Kadûnas, V., Budavièius, R., Gregorauskienë, V., Katinas, V., Kliaugienë, E., Radzevièius, A. and Taraðkevièius, R., 1999, Lietuvos geocheminis atlasas [Geochemical Atlas of Lithuania], Vilnius, 91 p. + 162 maps.

Kelly, C. and Lunn, R.J., 1999, Development of a contaminated land assessment system based on hazard to surface water bodies, Water Research, v. 33(6), pp. 1377-1386.

Lehmann, A. and Stahr, K., 2007, Nature and significance of anthropogenic urban soils. In: Journal of Soils and Sediments (online). v. 7(4).

Lerner, D.N. and Harris, B., 2009, The relationship between land use and groundwater resources and quality, Land Use Policy, v. 26(1), S265-S273.

Mather, J.D., Spence, I.M., Lawrence, A.R. and Brown, M.J., 1996, Manmade hazards. In: McCall, E.J.H., de Mulder, E.F.J. and Marker, B.R., (Eds.), Urban geoscience. AGID Special Publication Series 20, Balkema (Rotterdam), pp. 127-161.

Menzzano, A., Huelmo, S. and Satkunas, J., 2011, The occurrence of technosols in Montevideo city, Uruguay. Lithuanian Journal Geologija, v. 53, no. 4(76), pp. 187-191.

Mikðys R. B., Marcinkevièius V., Mikulënas V., 2002, Human factors in landsliding processes of Lithuania. In: Landslides: Proceedings of the First European Conference on Landslides, Prague, Czech Republic, June 24-26, 2002. A. A. Balkema, pp. 251-254.

Mitamura, M., 2003, Artificial valley fill and reclaimed pond area the 1995 Hanshin-Awaji Earthquake Disaster. Urban Kubota, Kubota Co. Ltd. Osaka. no. 40, pp. 26-37 [in Japanese].

Mitamura, M., Fujiwara, M., Hirai, M. and Murata, R., 2011, Distribution of valley fill in the Quaternary hilly area, Osaka, Japan. Journal of Geosciences, Osaka City University, v. 54(2), pp. 17-29

Musson, R.M.W. and Winter, P.W., 1997, Seismic hazard maps for the UK. Natural Hazards, v. 14(2-3), pp. 141-154.

Nathanail, C.P. and Bardos, P., 2004, Reclamation of contaminated land. John Wiley (Chichester) $250 \mathrm{p}$.

Nirei, H., Furuno, K., and Kusuda, T., 2010, Medical Geology in Japan. Medical Geology (a Regional Synthesis). International Year of Planet Earth (IYPE), Selinus, O. et al. (eds.), Springer, pp. 329-354.

Nirei, H., Furuno, K., Kazaoka, O., Marker, B. and Satkunas, Jonas, (2012), Classification of man-made strata for assessment of geopollution, Episodes, v. 35, pp. 333-336.

Õberg, T., 2005, A review of probabilistic assessment of contaminated land. Journal of Soils Sediments, v. 5(4), pp. 213-224

Office of the Deputy Prime Minister, 2004, Planning and pollution control. Planning Policy Statement 23. The Stationery Office (Norwich), v+12 p.
Paukðtë, V. and Mikulënas V., 2004, Kauno miesto geologinës informacijos duomen $\varnothing$ bazës sukûrimas. Pilto grunto storiø ir paplitimo pemëlapis M 1:10 000. [title in English] Aiškinamasis raštas. (Vilnius): LGT GF, $19 \mathrm{p}$.

Pearce, B.I., 1992, The effectiveness of the British land use planning system, Town Planning Review, v.63(10), pp. 13-28.

Petts, J., Cairney, T. and Smith, M., 1997, Risk based contaminated land investigation and assessment. John Wiley (New York) 334 p.

Rossiter, D.G., 2006, Proposal for a new reference group for the World Reference Base for Soils Resource (WRB) 2006, The Technosols.

Rossiter D.G., 2007, Classification of Urban and industrial Soils in the World Reference Base for Soil Resources. Journal of Soils and Sediments, v. 7(2), pp. 96-100.

Satkûnas J., Gregorauskienë V., Kanopienë R., Mikulënas V., Minkevièius V., Đaèkus V., Šlauteris A., 2011, Man made formations and geopollution state-of-art of knowledge in Lithuania. Geologija. Vilnius. v. 53, no.1(73), pp. 36-43.

Satkûnas, J., MikĐys, R.-B., Mikulënas, V. and Minkevièıus, V., 2008 Geodinaminiai procesai Vilniaus piliø teritorijoje: ðlaitø deformacijos [Geodynamic Process in the territory of Vilnius Castles: Deformations of the Slopes], Lietuvos Philys. Nr., v. 4, pp. 62-68.

Simms, D.L. and Beckett, M.J., 1987, Contaminated land: setting trigger concentrations, Science Total Environment, v. 65, pp.121-134.

Steeds, J.E., Slade, N.J. and Reed, M.W., 2000, Technical aspects of site investigation, v. II, Text supplements Research and Development Technical Report, P5-065/TR, Environment Agency (London), iii+149pp plus appendices.

Sugihara Kaoru, 1990, Japan as an engine of Asian international economy c1880-1936, Japan Forum, v. 2(1), pp. 127-145.

Teich, M. and Porter, R., (Eds.), 1996, The industrial revolution in national context: Europe and the USA, Cambridge University Press (Cambridge), $440 \mathrm{p}$

Tokunaga, S., 1996, Soil pollution: state-of-the-art in Japan and soil washing process. Clean Technology, v. 2(2), pp. 126-139.

Toshikazau, S., 2003, Contaminated soil remediation. Journal of Mining and Materials Processing Institute of Japan, v. 119(8), pp. 441-450.

Vaitkus, G., 2005, Lietuvos CORINE pemës dangos duomen $\varnothing$ baziø panaudojimo galimybiø studija. Aplinkos apsaugos agentûra, Vilnius, 61 p.

Wimpey Environmental Ltd with National House Building Council, 1995, Foundation conditions in GB: a guide for planners and developers. Wimpey Environmental Ltd (London), viii+183+40pp.

Younger, P.L., 2001, Mine water pollution in Scotland: nature, extent and preventative strategies, Science of the Total Environment, v. 265(1-3), pp. 309-326. 